\title{
CYTOKERATIN 16 EXPRESSION DOES NOT INDICATE CHOLESTEATOMA AGGRESSIVENESS
}

\author{
Badr Eldin Mostafa, Magda Salah Eldin El-Monayeri, Lobna Elfiky, \\ Mohammed Ashraf Mohammed, Abdel Rehim Sarwat
}

Department of Otorhinolaryngology Head and Neck Surgery and Department of Pathology, Ain-Shams University Faculty of Medicine, Cairo, Egypt

Corresponding author: Badr Eldin Mostafa, Professor of Otorhinolaryngology, Faculty of Medicine, Ain-Shams University, 48 Ibn El Nafees Street, 11371 Nasr City, Cairo, Egypt, e-mail: bemostafa@med.asu.edu.eg

\begin{abstract}
Aims: Cholesteatoma is characterised by a squamous epithelium in the middle ear and aggressive destructive behavior. A hyperproliferative epithelium also typically has an overexpression of cytokeratin 16 (CK16). The aim of this study was to compare CK16 expression in cholesteatoma epithelium and the epithelium of simple dry perforations.

Methods: Samples were obtained from 60 patients: 30 with cholesteatoma and 30 with simple perforations. The epithelium was immunohistochemically stained for CK16. Correlations were made between the clinical picture and the absence or presence of complications in both groups.
\end{abstract}

Results: Immunohistochemical staining for CK16 was positive in 45\% of specimens taken from the edge of simple perforations and in $51 \%$ of specimens taken from the cholesteatoma matrix. The difference was not statistically significant.

Conclusion: Two implications of our findings may be suggested: in cases of cholesteatoma the change in CK expression from normal epithelium is not the only factor which makes cholesteatoma aggressive; alternatively, in normal tissue the edge of a simple perforation is not as stable as is thought so that at least $45 \%$ of perforations can show hyperproliferative activity. It is therefore unclear whether hyperproliferative activity in either cholesteatoma or a simple perforation is a marker of instability or of attempts at healing.

Key words: cholesteatoma $\bullet$ chronic suppurative otitis media $\bullet$ cytokeratins

\section{LA EXPRESIÓN DE CITOQUERATINA 16 NO INDICA AGRESIVIDAD DEL COLESTEATOMA}

\section{Extracto}

Objetivos: El colesteatoma se caracteriza por un epitelio escamoso en el oído medio y un comportamiento agresivo y destructor. Un epitelio hiperproliferativo también suele tener sobreexpresión de citoqueratina 16 (CK16). El objetivo de este estudio fue comparar la expresión de CK16 en el epitelio del colesteatoma y el epitelio de perforaciones secas simples.

Métodos: Las muestras fueron obtenidas de 60 pacientes: 30 con colesteatoma y 30 con perforaciones simples. El epitelio fue teñido inmunohistoquímicamente para CK16. Se hicieron correlaciones entre el cuadro clínico y la ausencia o presencia de complicaciones en ambos grupos.

Resultados: La tinción inmunohistoquímica para CK16 fue positiva en el 45\% de las muestras tomadas del borde de perforaciones simples y en el $51 \%$ de las muestras tomadas de la matriz del colesteatoma. La diferencia no fue estadísticamente significativa.

Conclusión: Nuestro descubrimiento puede sugerir dos implicaciones: en casos de colesteatoma, el cambio en la expresión de CK del epitelio normal no es el único factor que hace que el colesteatoma sea agresivo; alternativamente, en el tejido normal el borde de una perforación simple no es tan estable como se piensa, de modo que por lo menos el $45 \%$ de las perforaciones pueden mostrar actividad hiperproliferativa. Por lo tanto, no está claro si la actividad hiperproliferativa tanto en el colesteatoma como en una perforación simple es un indicador de inestabilidad o de tentativas de cura.

Palabras clave: colesteatoma • otitis media supurativa crónica • citoqueratinas 


\section{ЭКСПРЕССИЯ ЦИТОКЕРАТИНА 16 НЕ УКАЗЫВАЕТ НА АГРЕССИВНОСТЬ ХОЛЕСТЕАТОМЫ}

\section{Резюме}

Задачи: Холестеатома характеризуется сквамозным эпителием в среднем ухе и агрессивным деструктивным поведением. Гиперпролиферативный эпителий также имеет типическую надэкспрессию цитокератина 16 (СК16). Цель настоящей работы - сравнить экспрессию СК16 эпителия холестеатомы и эпителия обычных сухих перфораций.

Методы: Пробы отобраны у 60 пациентов: 30 с холестеатомой и 30 с обычными перфорациями. Эпителий был иммуногистохимически окрашен СК16. Сделаны взаимосвязи между клинической картиной и отсутствием или наличностью усложнений в обеих группах.

Результаты: Иммуногистохимическое окрашивание СК16 было положительным для 45\% образцов, взятых на краю обычных перфораций и 51\% образцов, взятых из холестеатомной оболочки. Разница статистически незначительная.

Заключение: Из полученных нами данных можно сделать два выводы: в случае холестеатомы изменение экспрессии СК с нормального эпителия не является единственным фактором, который ведет к агрессивности холестеатомы; или же, в нормальной ткани край обычных перфораций не столь стабилен как предполагалось, так что, по крайней мере, $45 \%$ перфораций может проявлять гиперпролиферативную активность. Поэтому неясно, есть ли гиперпролиферативная активность в холестеатоме или обычных перфорациях маркером нестабильности или попыток лечения.

Ключевые слова: холестеатома • среда хронического суппуративного отита • цитокератины

\section{Introduction}

Cholesteatoma is typified by the presence of squamous epithelium in the middle ear cleft which is typically lined by a ciliated pseudostratified epithelium. The origin of this epithelium is still controversial. The main characteristic of this epithelium is its aggressive behavior, with bone erosion, lysis of the ossicular chain, and frequent complications. The pathological origin of the aggressive behavior is multifactorial and has not been fully elucidated. One possibility is an abnormal hyperproliferation of invasive/metaplastic epithelium [1]. On the other hand, the epithelium at the edges of a simple central perforation is also classified squamous, but is assumed to be in a more stable inactive state.

Cytokeratins are intermediate filament proteins of the cytoskeleton of epithelial origin. Two distinct differentiation pathways in human keratinocytes are described: terminal differentiation characterised by massive production of CK1 and $\mathrm{CK} 10$ and a regenerative pathway characterised by the expression of CK6 and CK16. CK16 expression is associated with wound healing and hyperproliferation in normal and transformed squamous epithelia [2]. The aim of this work was to compare CK16 expression between the cholesteatoma matrix and the stable epithelial edges of central dry perforations; the question was whether there was a difference in the proliferative activity of these types of epithelium which could explain this difference of behavior.

\section{Material and Methods}

This study comprised 60 specimens: 30 from patients with cholesteatoma and 30 from patients with simple dry stable perforations. The specimens from cholesteatoma patients were sampled from the advancing front of the sac. Those from simple perforations were taken from the junctional zone at the edge of the perforation. Both sets were examined histologically by haematoxylin and eosin and immunohistochemically for CK16 expression.

\section{Technique}

Sections were deparrafinised with xylene and rehydrated by serial alcohol solutions. They were then processed by the avidin-biotin peroxidase complex method. The chromogen used was DAB with $0.3 \%$ hydrogen peroxide (DBS, Pleasanton, CA, USA). The primary antibody was anti CK16 (clone EP1615Y, Epitomics, Burlingame, CA, USA). Finally, the specimens were counterstained by Mayer's haematoxylin for 1-10 minutes, rinsed in tap water, and mounted. The expression of CK16 in the suprabasal layers and its pattern of distribution (patchy or diffuse) were recorded.

\section{Statistical analysis}

Statistical analysis was performed using Graphpad Prism 5 v.5.00 for Windows. Data was compared using Fisher's two-sided exact test (alpha $<0.05$ ).

\section{Results}

\section{Patient}

Simple perforation

The mean age for patients was 32.4 yrs $(8-54, \mathrm{SD} \pm 12.5)$. The mean duration of disease was 5.59 yrs $(1-10, \mathrm{SD} \pm 3.1)$. The mean conductive loss was $22.5 \mathrm{~dB}$ (10-40 dB, SD $\pm 10.86)$ and the mean sensorineural loss was $13.52 \mathrm{~dB}$ (0-40 dB, SD \pm 6.69$)$. No cases showed ossicular chain lysis or bone erosion. 


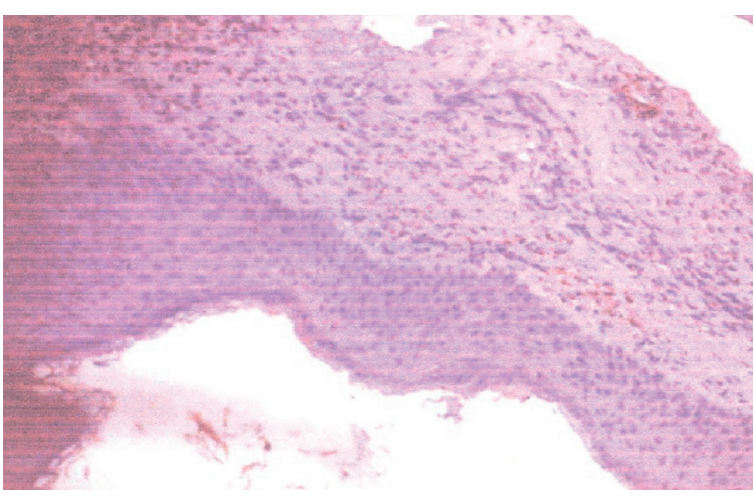

Figure 1. Edge of simple perforation, negative staining (immunohistochemistry, ×400).

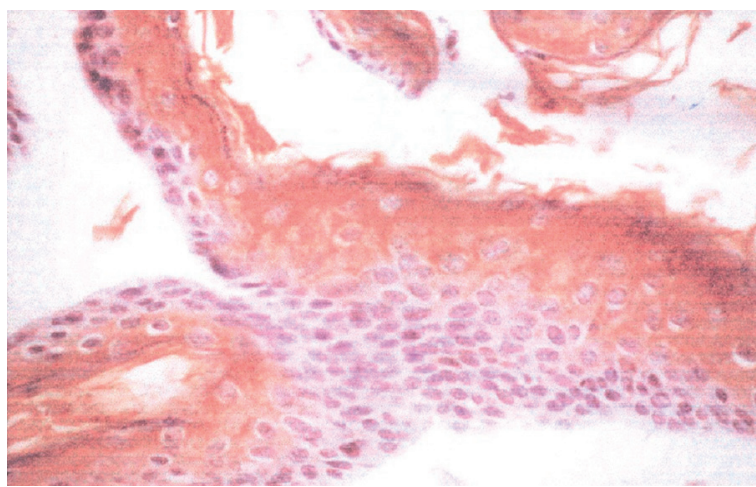

Figure 2. Edge of simple perforation, moderate basal and suprabasal staining (immunohistochemistry, $\times 400)$.

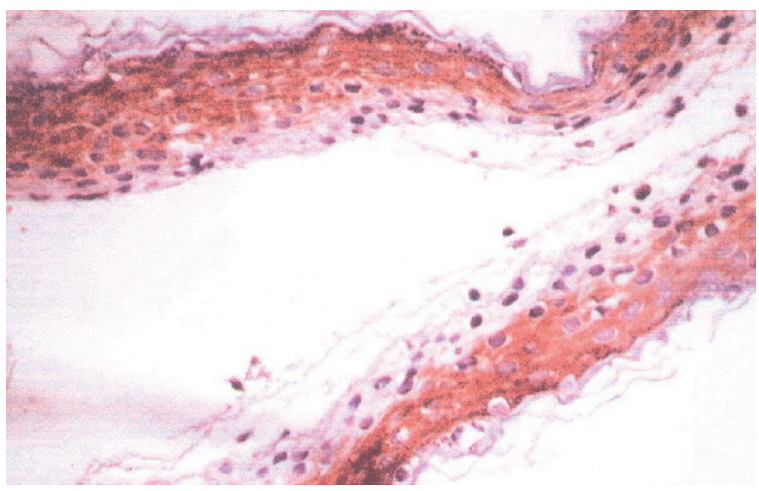

Figure 3. Edge of simple perforation, intense basal and suprabasal staining (immunohistochemistry, $\times 400)$.

Cholesteatoma

The mean age was 35.7 yrs $(17-52, \mathrm{SD} \pm 11.18)$. The mean duration of disease was 7 years $(1-20, S D \pm 4.84)$. The mean conductive loss was $17.57 \mathrm{~dB}(0-140 \mathrm{~dB}, \mathrm{SD} \pm 12.17)$. The mean sensorineural loss was $13.63 \mathrm{~dB}(0-40 \mathrm{~dB}, \mathrm{SD} \pm 8.60)$. Ossicular chain lysis was present in 15 cases (50\%) while attic erosion and other forms of bone erosion were present in 20 cases $(66.6 \%)$.

There was no statistical difference between both groups regarding any of these characteristics.

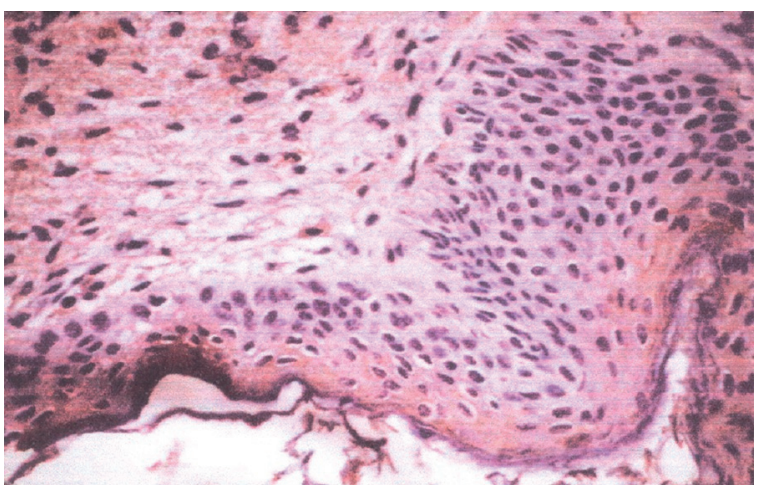

Figure 4. Cholesteatoma matrix, faint suprabasal staining (immunohistochemical staining, $\times 400$ ).

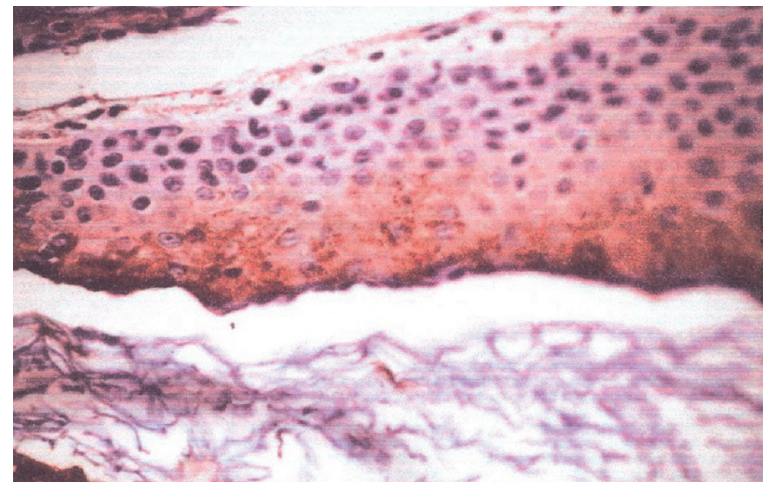

Figure 5. Cholesteatoma matrix, moderate basal and suprabasal staining (immunohistochemical staining, $\times 400)$.

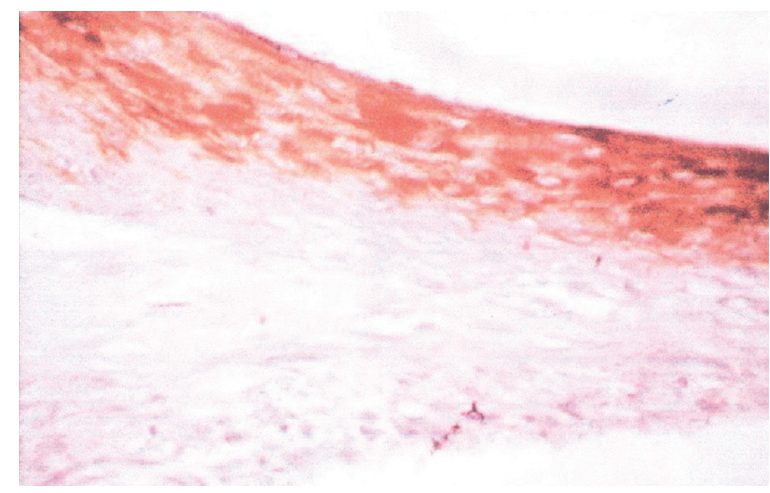

Figure 6. Cholesteatoma matrix, intense basal and suprabasal staining (immunohistochemical staining, $\times 400)$.

\section{Histology}

\section{Simple perforations}

The front of thickened epidermis frequently showed basal projections into the connective tissue. The adjacent middle ear epithelium was composed of flat to cuboidal cells. There was a gradual transition between both types in all specimens. At the muco-epidermal junction the lamina propria showed an accumulation of mononuclear inflammatory cells and capillaries. 


\section{Cholesteatoma}

The front edge showed papillary ingrowth and a varying degree of hyperplasia and dysplasia. The epithelium had few layers. The stratum corneum included several layers of acidophilic keratinising cells. The basement membrane was absent in certain areas with macrophage infiltration. Lymphocytes and plasma cells were also present in an inflammatory granulation reaction at certain points.

\section{Immunohistochemistry}

Simple perforations

Supra-basal staining of the epithelium was positive in $45 \%$ of specimens. In $27 \%$ the staining was intense whereas it was faint in $18 \%$. The staining extended to a varying number of suprabasal cell layers. In $43 \%$ of the positive specimens the staining was patchy with interspersed areas negative for CK16. In the remaining specimens the positivity was diffuse throughout (Figures 1-3).

\section{Cholesteatoma}

Suprabasal staining was positive in $51 \%$ of cases. In $24 \%$ it was intense while in the remaining $27 \%$ it was mild. There was no correlation between the degree of staining and either the stage of cholesteatoma, its invasiveness, or ossicular lysis. In $48 \%$ of cases the staining was patchy and in the remaining it was diffuse (Figures 4-6).

\section{Statistical analysis}

Contingency tables for the results are shown in Tables 1-3. There was no statistically significant difference between the degrees of CK16 positivity between the two groups. Similarly there was no difference in the type of staining, whether diffuse or patchy.

Within each group there was no difference in the rates of CK16 positivity and any of the studied variables (age of the patient, duration of the disease, degree of hearing loss). Additionally, in the cholesteatoma group there was no correlation between CK 16 expression and the presence of ossicular lysis, bone destruction, or the presence of a complication.

\section{Discussion}

The nature and origin of the epithelium in acquired cholesteatoma is unclear. Despite the morphological and biological similarities between the subepithelial layers in cholesteatoma and in chronic otitis media without cholesteatoma, there is a great difference in the aggressiveness and potential for complications in cholesteatoma $[3,5]$. This may be attributed to a change in the proliferative activity of the cholesteatoma epithelium. In normal epithelium only the basal layer is mitotically active. All hyperproliferative disorders of the skin show a disturbed architecture and enhanced expression of the acidic keratin CK16 [4]. This marker has been proposed as a molecular marker of hyperproliferation in normal and transformed epithelium [5]. The pattern of cytokeratin expression within a particular epithelium varies with its anatomical location,
Table 1. Comparison between CK16 positivity in cholesteatoma and simple perforations ( $p=1, \mathrm{~ns})$.

\begin{tabular}{ccc}
\hline & Positive & Negative \\
\hline Cholesteatoma & 15 & 15 \\
\hline Simple perforation & 14 & 16 \\
\hline
\end{tabular}

Table 2. Comparison between CK16 intense staining in cholesteatoma and simple perforations $(p=1$, ns).

\begin{tabular}{ccc}
\hline & Positive & Negative \\
\hline Cholesteatoma & 7 & 23 \\
\hline Simple perforation & 8 & 22 \\
\hline
\end{tabular}

Table 3. Comparison between CK16 faint staining in cholesteatoma and simple perforations ( $p=0.53$, ns).

\begin{tabular}{ccc}
\hline & Positive & Negative \\
\hline Cholesteatoma & 8 & 22 \\
\hline Simple perforation & 5 & 25 \\
\hline
\end{tabular}

developmental stage, and state of activity. The working hypothesis of this work was that the epithelium forming the cholesteatoma matrix was different in its proliferative activity compared to the stable, apparently inactive epithelium of simple perforations.

However, in our work immunohistochemical staining for CK16 was positive in $45 \%$ of specimens from the edge of simple perforations and positive in $51 \%$ of specimens from the cholesteatoma matrix. This was not statistically significant. Similarly, the distribution of positively staining cells - whether diffuse or patchy - was not significantly different between the two groups and did not correlate with any clinical manifestation such as ossicular lysis, bone erosion, or sensorineural hearing loss.

These findings are in contrast with the findings of Vennix et al. [3] who demonstrated an extension of CK16 expression to the suprabasal layers in cholesteatoma. Similarly, Kim et al. [6] in a gerbilline experimental cholesteatoma showed evidence of increased CK13/16 expression and suggested that the epithelium of the tympanic membrane undergoes changes in terminal differentiation as it forms a cholesteatoma. Other authors have shown a difference in CK expression between the tympanic membrane epithelium which was devoid of CK16 reactivity and the cholesteatoma epithelium which was consistently reactive $[7,8]$. Our findings do not decide the origin of the cholesteatoma epithelium but they do indicate that the behavior of the cholesteatoma matrix epithelium and that at the edge of tympanic membrane perforations have a similar hyperproliferative activity.

Two implications of our findings may be suggested: in cases of cholesteatoma the change in CK expression from normal epithelium is not the only factor which makes 
cholesteatoma aggressive; alternatively, in normal tissue the edge of a simple perforation is not as stable as is thought so that at least $45 \%$ of perforations can show hyperproliferative activity. It is therefore unclear whether hyperproliferative activity in either cholesteatoma or a simple perforation is a marker of instability or of attempts at healing.

\section{References:}

1. Kim HJ, Tinling SP, Chole RA: Expression patterns of cytokeratins in cholesteatoma: evidence of increased migration and proliferation. J Korean Med Sci, 2002; 17(3): 381-88

2. Moll R, Franke WW, Schiller DL: The catalog of human CK: patterns of expression in normal epithelia, tumours and cultured cells. Cell, 1982; 31: 11-24

3. Vennix P, Kuijpers W, Peters T et al: Keratinocyte differentiation in acquired cholesteatoma and perforated tympanic membranes. Arch Otorhinolaryngol Head Neck Surg, 1996; 122: 825-32

4. Olszewska E, Sudhoff H: Comparative cytokeratin distribution patterns in cholesteatoma epithelium. Histol Histopathol, 2007; 22(1): 37-42
5. Sasaki H, Huang CC: Expression of cytokeratins 13 and 16 in middle ear cholesteatoma. Otolaryngol Head Neck Surg, 1994; 110(3): $310-17$

6. Lee RJ, Sidey C, Narula AA, James RF: The nature of the epithelium in acquired cholesteatoma: Part 3 - Cytokeratin patterns in aural epithelial and cholesteatoma cells grown in cell culture. Clin Otolaryngol Allied Sci, 1994; 19(6): 516-20

7. Kim HJ, Tinling SP, Chole RA: Expression patterns of cytokeratins in retraction pocket cholesteatomas. Laryngoscope, 2001; 111(6): 1032-36

8. Bujia J, Schilling V, Holly A et al: Hyperproliferation-associated keratin expression in human middle ear cholesteatoma. Acta Otorhinolaryngol (Stockh), 1993; 113: 364-68 